Human insulin in general offers no advantage over highly purified animal insulins. ${ }^{30}$ Patients should therefore be transferred to human insulin only when there is a medical indication, under a doctor's guidance, and after having been informed that a change in symptoms of hypoglycaemia could occur. As advocated previously, ${ }^{31}$ a large randomised clinical trial is now needed to establish definitively whether there is an increased risk of severe hypoglycaemia associated with transfer to human insulin.

We thank Baxter AG, Medisense, CH-8305 Dietikon, for providing glucose meters and test strips; Yoav Ben-Shlomo, Lucy Carpenter, Peter Diem, and Martin Shipley for comments on an earlier draft; and Donat Gemsch for help with the data collection.

\footnotetext{
I Berger WG, Althaus BU. Reduced awareness of hypoglycemia after changing from porcine to

2 Teuscher A, Berger WG. Hypoglycaemia unawareness in diabetics transferred to human insulin. Lancet 1987; ;i:382-5.

to human insuln. Lancet 1987;11:382-5.
Berger WG, Keller U. Honegger B, Jaeggi E. Warning symptoms of Berger WG, Keller U. Honegger B, Jaeggi E. Warning symptoms of
hypoglycaemia during treatment with human and porcine insulin in diabetes mellitus. Lancet 1989;i:1041-4.

4 Hepburn DA, Frier BM. Hypoglycaemic unawareness and human insulin. Lancet 1989;i:1394.

5 Egger M, Davey Smith G, Imhoof $\mathrm{H}$, Teuscher A. Risk of severe hypoglycaemia in insulin diabetic patients transferred to human insulin. BMF 1991;303:617-21.

6 Matthews DR, Holman RR, Bown E, Steemson J, Watson A, Hughes S, et al. Pen-sized digital 30-second blood glucose meter. Lancet 1987;i:778-9.

7 Lefebvre PJ, Scheen AJ. Hypoglycaemia. In: Rifkin H, Porte D, eds Ellenberg and Rifkin's diabetes mellitus. 4th ed. New York: Elsevier, 1990 .

8 Ewing DJ, Clarke BF. Autonomic neuropathy: its diagnosis and prognosis. Clinics in Endocrinology and Metabolism 1986;15:855-88.

9 Gautschy B, Weidmann P, Gnädinger MP. Autonomic function tests as related to age and gender in normal man. Klin Wochenschr 1986;64:499-505.

10 Armitage P, Berry G. Statistical methods in medical research. 2nd ed. Oxford: Blackwell Scientific Publications, 1988.

11 Hosmer DW, Lemeshow S. Applied logistic regression. New York: John Wiley, 1989.

12 Pocock SJ. Clinical trials. A practical approach. New York: John Wiley, 1983.
}

13 Clark AJL, Adeniyi-Jones RO, Knight (G, Leiper JM, Wiles PG, Jones RH, $e$ al. Biosynthetic human insulin in the treatment of diabetes. Lance 1982;ii:354-7.

14 Peacock I, Tattersall RB, Taylor A, Douglas CA, Reeves WG. Effects of new insulins on insulin and C-peptide antibodies, insulin dose, and diabetic control. Lancet 1983;i:149-52.

15 Home PD, Mann NP, Hutchison AS, Porte R, Walford S, Murphy M, Reeve WG, et al. A fifteen month double-blind cross-over trial of the efficacy and antigenicity of human and pork insulins. Diabetic Med 1984;1:93-8.

16 Cryer PE. Counter-regulation. In: Rifkin H, Porte D, eds. Ellenberg and Rifkins diabetes mellitus. 4th ed. New York: Elsevier, 1990.

17 Smith RJ. Hypoglycaemia. In: Marble A, Krall LP, Bradley RF, Christlieb AR, Soeldner JS. Foslin's diabetes mellitus. 12th ed. Philadelphia: Lea and Febiger, 1985 .

18 Froesch ER. Pathophysiological and clinical aspects of hypoglycaemia. In Labhart A. Clinical endocrinology. Theory and pratice. Berlin: Springer Verlag, 1986:841.

19 Egger M, Teuscher A, Berger W. Hypoglycaemia unawareness: human vs. animal insulin. Diabetologia 1988;31:453-4.

20 The DCCT research group. Diabetes control and complications trial (DCCT) Results from the feasibility study. Diabetes Care 1987;10:1-19.

21 Ryder REJ, Owens DR, Hayes TM, Ghatei MA, Bloom SR. Unawareness of hypoglycaemia and inadequate hypoglycaemic counterregulation: no causal hypoglycaemia and inadequate hypoglycaemic counterregulation: no
relation with diabetic autonomic neuropathy. $B M \mathcal{A} 1990 ; 301: 783-7$

22 Amicl SA, Tamborlane WV, Simonson DC, Sherwin RS. Defective counter miel SA, Tamborlane WV, Simonson DC, Sherwin RS. Defective counter-
regulation after strict glycemic control of insulin-dependent diabetes regulation after strict glycemic control
mellitus. $N$ Engl J Med 1987;316:1376-83.

23 Jakober B, Lingenfelser T, Glück H, Maassen T, Overkamp D, Renn W, et al. Symptoms of hypoglycemia - a comparison between porcine and human insulin. Klin Wochenschr 1990;68:447-53.

24 Schlüter KJ, Pete. -n KG, Sontheimer J, Enzmann F, Kerp L. Differen counterregulatory responses to human insulin (recombinant DNA) and purified pork insulin. Diabetes Care 1982;5(suppl 2):78-81.

25 Heine RJ, van der Heyden EAP, van der Veen EA. Responses to human and porcine insulin in healthy subjects. Lancet 1989;ii:946-8.

26 Kern W, Born J, Kerner W, Fehm HL. Counter-regulatory hormone responses to human and porcine insulin induced hypoglycaemia. Lance 1989;ii:485.

27 Tattersall RB, MacDonald IA. Human insulin. BMf 1989;299:339.

28 Markussen J, Damgaard U, Johansen NL, Sörgensen KM, Sorensen E, Thim L. Charakterisierung des aus Schweineinsulin präparierten Humaninsulin. Aktuelle Endokrinologie 1981;1:104-14.

29 Kern W, Lieb K, Kerner W, Born J, Fehm HL. Different effects of human and porcine insulin-induced hypoglycemia on neuronal functions in man. 39.1091-8.

. Human insulin. RMF 1986;292:155-7.

31 Cryer PE. Human insulin and hypoglycemia unawareness. Diabetes Care 1990;13:536-7.

(Accepted 11 fuly 1991)
St George's Hospital Medical School, London SW17 0RE

G A Haywood, MRCP, British Heart Foundation junior fellow

A J Camm, FRCP, professor of clinical cardiology

St Peter's Hospital, Chertsey, Surrey

M D Joy, FRCP, consultant physician

Correspondence to:

Professor Camm.

BMf 1991;303:626-7

\section{Influence of posture and reference point on central venous pressure measurement}

\section{G A Haywood, M D Joy, A J Camm}

Measurement of central venous pressure has been used as an indicator of the adequacy of transfusion for more than 20 years. $^{12}$ Despite the familiarity of the technique, there seems to have been little emphasis placed on the degree of variation in measurements caused by the patient's posture and the choice of reference point. Early reports emphasised the importance of measuring from the mid-axilla with the patient supine, ${ }^{2}$ but this is not always practicable, particularly when patients are too breathless to tolerate lying flat. We determined the degree of variation in values for central venous pressure taken from two different reference points and with two different patient positions.

\section{Patients, methods, and results}

Twenty five patients who required monitoring of their central venous pressure had a standard $18 \mathrm{~cm}$ central venous cannula inserted by one of us $(\mathrm{GH})$ through the right internal jugular vein. The cannula was connected to a bedside saline manometer, and free antegrade flow of saline and retrograde flow of blood was established by raising and lowering the reservoir. In all cases the column of saline fell rapidly on opening the tap to the patient and at the equilibration point the meniscus was observed to move with respiration. A mean value between the swings observed with respiration was recorded. Patients were asked to breathe as gently as possible while the recordings were being made. Four sets of readings were taken: $(a)$ from the sternal angle with the patient's torso at $45^{\circ} ;(b)$ from the sternal angle with the patient lying flat; $(c)$ from the mid-axillary line at the level of the fourth intercostal space with the patient lying at $45^{\circ}$; and $(d)$ from the mid-axillary line at the level of the fourth intercostal space with the patient lying flat. In all cases readings

Central venous pressure measurements $\left(\mathrm{cm} \mathrm{H}_{2} \mathrm{O}\right)$ in 25 patients taken from sternal angle or mid-axilla and with patient at $45^{\circ}$ or lying flat

\begin{tabular}{|c|c|c|c|c|c|}
\hline \multirow[b]{2}{*}{ Patient No } & \multirow[b]{2}{*}{$\begin{array}{c}\text { Age } \\
\text { (years) }\end{array}$} & \multicolumn{4}{|c|}{ Central venous pressure $\left(\mathrm{cm} \mathrm{H}_{2} \mathrm{O}\right)$} \\
\hline & & $\begin{array}{c}\text { Sternal } \\
\text { angle, } 45^{\circ}\end{array}$ & $\begin{array}{c}\text { Sternal } \\
\text { angle, flat }\end{array}$ & $\underset{45^{\circ}}{\text { Mid-axilla, }}$ & $\begin{array}{c}\text { Mid-axilla, } \\
\text { flat }\end{array}$ \\
\hline 1 & 75 & $-13 \cdot 0$ & $-4 \cdot 0$ & $-1 \cdot 0$ & $3 \cdot 5$ \\
\hline 2 & 45 & $-12 \cdot 0$ & $-3 \cdot 0$ & 0.0 & $4 \cdot 0$ \\
\hline 3 & 28 & $-10 \cdot 0$ & -1.5 & $-1 \cdot 0$ & $7 \cdot 0$ \\
\hline 4 & 65 & $-9 \cdot 0$ & $-3 \cdot 5$ & $2 \cdot 5$ & $3 \cdot 0$ \\
\hline 5 & 55 & $-8 \cdot 5$ & $-8 \cdot 0$ & $6 \cdot 5$ & $4 \cdot 5$ \\
\hline 6 & 74 & $-8 \cdot 0$ & $-6 \cdot 5$ & $5 \cdot 5$ & $4 \cdot 5$ \\
\hline 7 & 49 & $-6 \cdot 5$ & $-4 \cdot 5$ & $7 \cdot 0$ & $8 \cdot 0$ \\
\hline 8 & 64 & $-6 \cdot 0$ & $-2 \cdot 0$ & $6 \cdot 0$ & $11 \cdot 0$ \\
\hline 9 & 60 & $-5 \cdot 0$ & $-2 \cdot 5$ & $11 \cdot 0$ & $8 \cdot 0$ \\
\hline 10 & 81 & $-5 \cdot 0$ & $-1 \cdot 0$ & 6.0 & $8 \cdot 0$ \\
\hline 11 & 79 & $-4 \cdot 0$ & 0.0 & $3 \cdot 0$ & $12 \cdot 0$ \\
\hline 12 & 80 & $-2 \cdot 0$ & $0 \cdot 0$ & $10 \cdot 5$ & $9 \cdot 0$ \\
\hline 13 & 65 & $-2 \cdot 0$ & $3 \cdot 5$ & $13 \cdot 5$ & $14 \cdot 0$ \\
\hline 14 & 65 & -1.5 & $13 \cdot 0$ & $12 \cdot 0$ & $20 \cdot 5$ \\
\hline 15 & 88 & -0.5 & $4 \cdot 5$ & $11 \cdot 5$ & $14 \cdot 0$ \\
\hline 16 & 51 & 0.0 & $8 \cdot 0$ & $14 \cdot 0$ & $17 \cdot 0$ \\
\hline 17 & 67 & 0.0 & $1 \cdot 0$ & $10 \cdot 0$ & $10 \cdot 0$ \\
\hline 18 & 76 & 0.0 & 0.0 & $7 \cdot 0$ & $6 \cdot 0$ \\
\hline 19 & 75 & $1 \cdot 0$ & $3 \cdot 5$ & $17 \cdot 5$ & $12 \cdot 5$ \\
\hline 20 & 36 & $1 \cdot 0$ & $3 \cdot 0$ & $12 \cdot 0$ & $14 \cdot 5$ \\
\hline 21 & 50 & 6.5 & $14 \cdot 0$ & $23 \cdot 0$ & $24 \cdot 5$ \\
\hline 22 & 79 & $7 \cdot 5$ & 11.5 & $20 \cdot 0$ & $22 \cdot 5$ \\
\hline 23 & 78 & $8 \cdot 5$ & 10.0 & $18 \cdot 5$ & $21 \cdot 5$ \\
\hline 24 & 74 & $8 \cdot 5$ & $8 \cdot 5$ & $23 \cdot 5$ & $19 \cdot 0$ \\
\hline 25 & 71 & $9 \cdot 5$ & $17 \cdot 5$ & $24 \cdot 5$ & $27 \cdot 0$ \\
\hline $\begin{array}{l}\text { Mean (SD) } \\
\text { Variance }\end{array}$ & & $\begin{array}{l}-2 \cdot 0(6 \cdot 5) \\
42 \cdot 4\end{array}$ & $\begin{array}{l}2.6(6 \cdot 8) \\
45.8\end{array}$ & $\begin{array}{l}10 \cdot 5(7 \cdot 5) \\
56 \cdot 4\end{array}$ & $12 \cdot 2(7 \cdot 1)$ \\
\hline Variance & & $42 \cdot 4$ & $45 \cdot 8$ & $56 \cdot 4$ & $49 \cdot 8$ \\
\hline
\end{tabular}


were taken over less than 15 minutes and less than $30 \mathrm{ml}$ of saline was infused.

The table gives the results. The lowest value measured for each patient occurred when readings were taken from the sternal angle with the patient's torso at $45^{\circ}$. The highest values were from the midaxillary line with the patient lying flat. The range of individual variation with different postures and reference points was $6-22 \mathrm{~cm} \mathrm{H}_{2} \mathrm{O}$. The mean (SD) difference between central venous pressure measured with the patient flat and that measured with the patient's torso at $45^{\circ}$ was $4.6(3.6) \mathrm{cm} \mathrm{H}_{2} \mathrm{O}$ when measured from the sternal angle $(\mathrm{p}<0.001)$ and $1 \cdot 7(3 \cdot 7) \mathrm{cm} \mathrm{H}_{2} \mathrm{O}$ from the mid-axillary line $(\mathrm{p}<0.03)$.

\section{Comment}

In surgical recovery areas, accident and emergency departments, and intensive care units central venous pressure is usually measured with the patient supine. After transfer to general wards it is more commonly measured with the patient sitting up in bed. Assuming the same reference point is used, the mean difference in the recorded measurements will be $4.6 \mathrm{~cm} \mathrm{H} \mathrm{H}_{2} \mathrm{O}$ from the sternal angle and $1.7 \mathrm{~cm} \mathrm{H}_{2} \mathrm{O}$ from the mid-axillary line. However, taking two standard deviations from the mean, there will be some patients in whom the disparity may be as great as $11.8 \mathrm{~cm} \mathrm{H}_{2} \mathrm{O}$ and $9.1 \mathrm{~cm}$ $\mathrm{H}_{2} \mathrm{O}$ respectively. This considerable variation results from many factors, including thoracic morphology, compliance of perivascular tissues, and venous tone. ${ }^{3}$ Unless doctors appreciate that such variation can exist without reflecting any change in the circulating volume, inappropriate management decisions may be made. It is essential that, wherever possible, the same method for measuring central venous pressure is used for each recording taken from a patient and that all readings must be qualified by the anatomical reference point and the patient's posture at the time of recording.

1 Sykes MK. Venous pressure as a clinical indication of the adequacy of transfusion. Ann R Coll Surg Engl 1963;33:185-97.

2 Wilson JN, Grow JB, Demong CV, Prevedel AE, Owens JC. Central venous pressure in optimal blood volume maintenance. Arch Surg 1962;85:563-77. 3 Blomqvist CG, Stone HL. Cardiovascular adjustments to gravitational stress. In: Shepherd JT, Abboud FM, Geiger SR, eds. Handbook of physiology (American Physiological Society). The cardiovascular system. Vol 3. The peripheral circulation. Part 2. Baltimore: Waverley Press, 1983:1025-63.

(Accepted 8 May 1991)

\section{Pneumothorax: a complication of fine needle aspiration of the breast}

\section{A Gateley, P R Maddox, R E Mansel}

\section{Department of Surgery, University Hospital of South Manchester, Manchester M20 8LR C A Gateley, FRCS, clinical research registrar \\ R E Mansel, FRCs, professor \\ Department of Surgery, University of Wales College of Medicine, Cardiff CF4 4XN \\ P R Maddox, FRCS, registrar}

Correspondence to:

Professor Mansel.

BMF 1991;303:627-8
Iatrogenic pneumothorax is a recognised complication of subclavian cannulation, intercostal nerve block, chest aspiration, needle aspiration lung biopsy, ${ }^{1}$ and supraclavicular brachial plexus block. ${ }^{2}$ Fine needle aspiration cytology is a standard procedure in diagnosing breast lumps ${ }^{3+}$ and has few complications. Indeed, most published papers do not mention complications happening during this procedure, which suggests that clinicians are unaware that serious complications may occasionally occur. The one major report that did present complications identified only minor bruising, which developed in a fifth of 1655 cases. ${ }^{4}$ Pneumothorax occurring after fine needle aspiration of the breast has not to our knowledge been reported; we present seven such cases.

\section{Case reports}

The table shows the clinical details of seven cases of iatrogenic pneumothorax after fine needle aspiration of breast lumps for diagnostic purposes. The cases occurred in the breast clinics of three teaching hospitals in Britain, in a clinic at a district general hospital, and in a general practice surgery over a period of 3 years. The two cases from centre A (cases 1 and 2) occurred during a 12 month period in which 449 solid lumps were aspirated for cytology and around 500 cysts were aspirated. No further cases have been reported in a subsequent 12 month period, giving a rough incidence of 1 in 1000 aspirations.

\section{Comment}

Symptomatic iatrogenic pneumothorax occurs rarely after fine needle aspiration of lumps in the breast, but clinicians performing such procedures should be aware of this potentially serious complication. We cannot calculate the exact incidence of this complication as many thousands of aspirations have been performed in the centres as a whole and, from experience of other procedures, asymptomatic pneumothoraces probably also occur. In most of our series the aspirations were performed at the periphery of the breast or in the axilla. Here the breast depth is minimal and proper fine needle aspiration technique, in which multiple passes are performed at different angles transfixing the breast lump, increases the risk of inadvertently breaching the pleura. Also, most breast lumps occur in the outer half of the breast and so more aspirations are performed there. In aspirating lumps at the periphery of the breast clinicians should try to pass the needle parallel to the chest wall rather than at right angles to it, as is conventional teaching.

Because this complication is rare, routine chest radiography after aspiration is not indicated. Patients should, however, be asked about new symptoms before being allowed home. In our study the patients presented late because they assumed that pain was a normal part of the aspiration procedure and they did not report the immediate pain from the pleural breach to the doctor in the clinic. Clinicians performing aspirations should therefore perhaps explain to their patients that chest pain persisting after the needle has been withdrawn is abnormal.

Patients who develop dyspnoea or any immediate

Clinical details of seven cases of iatrogenic pneumothorax after fine needle aspiration of the breast

\begin{tabular}{|c|c|c|c|c|c|c|c|c|c|}
\hline $\begin{array}{r}\text { Case } \\
\text { No } \\
\end{array}$ & Setting & $\begin{array}{c}\text { Age } \\
\text { (years) }\end{array}$ & Final diagnosis & Site of lesion & Grade of aspirator & $\begin{array}{c}\text { Onset of } \\
\text { symptoms of } \\
\text { pneumothorax }\end{array}$ & $\begin{array}{l}\text { Time to } \\
\text { presentation } \\
\text { (hours) }\end{array}$ & $\begin{array}{l}\text { Pneumothorax } \\
\text { managed by }\end{array}$ & $\begin{array}{c}\text { Method of } \\
\text { management }\end{array}$ \\
\hline 1 & Teaching hospital A, breast clinic & 43 & Cyst & Upper outer quadrant & Registrar & Immediate & 4 & General physician & Chest drainage \\
\hline 2 & Teaching hospital A, breast clinic & 50 & Benign nodularity & Upper outer quadrant & Senior house officer & Immediate & 48 & Chest physician & Observation \\
\hline 3 & General practice & 33 & Fibroadenoma & Axillary tail & $\begin{array}{l}\text { Principal general } \\
\text { practitioner }\end{array}$ & Immediate & 72 & Chest physician & Aspiration \\
\hline & Teaching hospital $\mathrm{B}$, breast $\mathrm{c}$ & 45 & Lym & Axil & Registrar & Immediate & Immediately & Sur & Obse \\
\hline 5 & Teaching hospital C, breast clinic & 42 & Benign lump & Upper outer $\mathrm{C}$ & Registrar & 6 hours & 24 & General physician & Chest drainage \\
\hline & Teaching hospital C, breast clinic & 37 & Benign lump & Upper outer quadrant & Registrar & 6 hours & 48 & General physician & Chest drainage \\
\hline 7 & District general hospital & 37 & Benign nodularity & Deep & Consultant & Immediate & 48 & General physician & Chest drainage \\
\hline
\end{tabular}

